\title{
The Relationship Between Test Anxiety and Achievement in Accounting Students with Different Cognitive Styles: The Mediating Roles of Self-Regulation
}

\author{
Pi-Yueh Cheng (Corresponding author) \\ Tainan University of Technology \\ Taiwan \\ E-mail: t20030@mail.tut.edu.tw
}

\author{
Wan-Ru Liao \\ Taiwan Shoufu University
}

Taiwan

$\begin{array}{lc}\text { Received: March 30, } 2016 & \text { Accepted: May 27, } 2016 \quad \text { Published: June 27, } 2016 \\ \text { doi:10.5296/ire.v4i2.9177 } & \text { URL: http://dx.doi.org/10.5296/ire.v4i2.9177 }\end{array}$

\begin{abstract}
Previous research has indicated that accounting is a very important basic course for undergraduate business and management students. Studies have also shown that most accounting teachers and students are anxious about their ability to effectively teach and learn the course curriculum, respectively, which may result in a poor outcome for the students. Attempts have been made to improve accounting education and reduce anxiety by enhancing students' learning strategies and reducing the stress related to testing. The purpose of this research was to establish and model the effects of accounting anxiety on achievement, to examine the mediating role of self-regulation in the relationship between test anxiety (TA) and achievement, and to compare the achievement and learning processes of students with different cognitive styles. Participants were 498 students from Taiwan business colleges. Our results revealed that self-regulated learning mediated the relationship between TA and accounting achievement. Additionally, with significant differences noted between students with analytical and intuitive cognitive styles. A discussion of study limitations and of implications for accounting education follows.
\end{abstract}


Keywords: accounting education, achievement, cognitive style, self-regulated learning, test anxiety

\section{Introduction}

Introductory accounting is a required course for all business majors at most universities. Unfortunately, research has indicated that most students majoring in introductory accounting have many negative, stereotypical perceptions of this course, often created or reinforced in introductory accounting courses (Cohen \& Hanno, 1993; Cory, 1992; Fisher \& Murphy, 1995; Friedlan, 1995; Saudagaran, 1996). The reason for this may lie in the definition of accounting itself. The definition provided by Warren, Reeve, and Duchac (2007) is given as an example: "an information system that provides reports to stakeholders about the economic activities and conditions of a business" (p. 7). Definitions such as this one present accounting as a boring, pencil-pushing subject, which causes anxiety for both teachers and students (Ameen et al., 2002; Borja, 2003; Buckhaults \& Fisher, 2011). For example, Borja (2003) indicated that all levels of students new to accounting may view the subject as equivalent in difficulty to learning a foreign language, which is known to cause extreme anxiety for most students. Buckhaults and Fisher (2011) suggested that accounting educators could decrease students' anxiety and increase their motivation to learn accounting by using appropriate materials and new teaching methods. Numerous studies of accounting education have focused on the relationship between student performance and the quality of the accounting curriculum, including cognitive processes in learning (e.g., Booth \& Mladenovic, 1999; Fisher \& Murphy, 1995; Lucas, 2000, 2001, 2002; Lucas \& Meyer, 2005; Mladenovic, 2000), learning approaches (e.g., Byrne et al., 1999; Byrne et al., 2002; Davidson, 2002), teaching content and performance (e.g., Gow et al., 1994; Koh \& Koh, 1999), learning style and attitude toward accounting (e.g., Chen et al., 2013; Duff, 2004), and cognitive preferences and cooperative learning among students (e.g., Ramsay et al., 2000). However, to date, the role of self-concept as it relates to accounting education has yet to be investigated, despite the well-known relationship among self-regulated learning (SRL), test anxiety (TA), and academic achievement.

Learning anxiety has been identified in many different curricula. For example, Hong (2010) indicated that outstanding students experience learning anxiety in cooperative learning of science. Onwuegbuzie (2004) determined that $\sim 80 \%$ of graduate students had statistics anxiety; thus, their research methods were poor. Zeidner (1991) also observed a high correlation between mathematics and statistics stress among social science students. Andrade et al. (2009) investigated Japanese students' anxiety when learning a foreign language. Dyck and Smither (1996) surveyed anxiety and learning attitudes among college seniors learning to use computers. Baloğlu and Çevik (2009) employed multilevel constructs to investigate anxiety associated with learning computers for newcomers and senior employees. Ameen et al. (2002) studied teaching anxiety among accounting professors in the United States and determined that the vast majority of respondents $(78 \%)$ had experienced teaching anxiety. Further, Buckhaults and Fisher (2011) identified accounting anxiety in educators and students as a possible explanation for the decline in accounting education; their study emphasized the need for new accounting teaching methods to reduce stress for both the teacher and students. 
Clark and Schwartz (1989) assessed the effect of behavioural interventions on the anxiety and achievement of accounting students. Their laboratory study indicated that the state anxiety scores of the participants in the treatment workgroup decreased post-treatment; however, the participant's scores during treatment and in the control workgroup remained relatively constant. Students' TA and the means to enhance students' achievement were not addressed in that study.

Chen et al. (2013) identified a significant relationship between learning attitude and anxiety among Taiwanese hospitality management students in accounting classes. Their research focused on the desire to learn, the students' study habits, and the exam methods of the students. However, the effects of SRL and self-efficacy on anxiety and learning achievement were not evaluated.

Past research has also found a wide range of effectiveness when specific learning strategies, such as SRL (e.g., Andrew \& Karen, 2011; Lee et al., 2012), were used to reduce TA. Moreover, the role of cognitive learning styles may affect students' learning achievement in accounting education (Duff, 2004). Thus, it is worthwhile to investigate the effect of SRL on TA and academic achievement with respect to individual differences in cognitive style among accounting students.

The purposes of the present study were (1) to examine students' anxiety in introductory accounting and to explore the relationship between TA and achievement; (2) to test the mediating role of SRL in the relationship between TA and achievement; and (3) to evaluate the effect of cognitive style on differences in learning behaviour.

\section{Literature and Research Hypotheses}

\subsection{Test Anxiety}

Anxiety is an unpleasant emotion experienced as fear, alarm, trepidation, horror, or panic (Lewis, 1970). Anxiety is also an emotional state characterized by feelings of tension, apprehension, and nervousness (Spielberger et al., 1983). Wilkinson and Campbell (1997) defined anxiety as a threat that leads an individual to feel anxious, nervous, and disturbed; they emphasized that the cause of anxiety is usually unknown or unclear. White and Farrell (2001) defined anxiety as a psychological state of being worried, alert, and/or restless. Kurt and Gurcan (2010) showed that anxiety may materialize as a state of excitement due to an unknown source and as a milder effect, but one that lasts longer than fear. Additionally, anxiety can be categorized as 'state anxiety' or 'trait anxiety.' According to Spielberger (1983), trait anxiety refers to the probability of experiencing state anxiety. Situation-specific anxiety is the probability of becoming anxious in a particular type of situation, such as during tests ("test anxiety"). Metacognitive beliefs are often associated with TA. Matthews et al. (1999) have shown a correlation of metacognitive beliefs with stress, thoughts unassociated with the test, and physical symptoms of TA. TA is a short-term state that occurs specifically during examinations (Onyeizugbo, 2010). Although past research has investigated TA with regard to different courses, such as mathematics, computers, English, and statistics, research on the relationship between TA and academic achievement in accounting courses has been 
very limited.

\subsection{Self-Regulated Learning (SRL)}

Academic self-regulation refers to self-generated, reflective, and strategic engagement in academic tasks (Zimmerman 2000). Recently, self-regulation has received considerable attention with regard to academic success in higher education. Indeed, a growing body of literature highlights the importance of SRL in the college classroom (Agina, 2012; Bembenutty, 2007; Cho \& Kim, 2013; Grau \& Whitebread, 2012; Printrich \& Zusho, 2007). Printrich (2000) defined self-regulation in academic settings as the "active, constructive process whereby learners set goals for their learning and then attempt to monitor, regulate, and control cognition, motivation, and behaviour, guided by their goals and the contextual features in the environment" (p. 453). Thus, the self-regulation system has the task of maintaining the 'self' of a person (Hanfstingl et al., 2010). Self-regulation also influences outcome expectations or the individual's beliefs that their course of action will result in the attainment of desirable outcomes (Bandura, 1997). In general, strategic learners have the skill, will, and self-regulation needed to be effective and efficient learners in varied educational environments (Weinstein et al., 2004). Although SRL has been investigated in various courses, few studies have addressed the TA experienced by accounting students, particularly those in Taiwan colleges and universities.

\subsection{Test Anxiety (TA) and Achievement}

Tests and examinations at all stages of education, especially in higher education, have been an important tool for decision making in competitive societies (Rana \& Mathmood, 2010). Thus, it is worth discussing several studies that show a significant relationship between TA and academic achievement. Previous studies indicated TA as an important predictive variable for academic achievement. For example, greater anxiety would be associated with poorer academic achievement (Onyeizugbo, 2010). Nicholson (2009) revealed a relationship between students' TA and their achievement. Khalid and Hasan (2009) indicated that undergraduate students with higher achievement may have lower TA. Similarly, low-TA students had higher achievement than did high-TA students (Akinleke, 2012). Thus, the present research proposed the following hypothesis:

$\mathrm{H}_{1}$ : There is a negative relationship between test anxiety (TA) and academic achievement in accounting courses.

\subsection{Self-Regulated Learning (SRL) as a Mediator}

Based on research covering a broad range of subjects, several studies have recently demonstrated the effectiveness of SRL in promoting students' learning skills, and thereby their academic achievement (Dignath \& Buttne,r 2008; Dignath et al., 2008). These results were aligned with the observations of Zimmerman (2000), who characterized a self-regulated learner as one involved in self-initiated engagement in the behavioural, metacognitive, and motivational processes that are necessary to master academic skills and accomplish one's goals in the domain of social-cognitive competencies. Thus, SRL plays a crucial role in the process of promoting students' academic achievement. Past studies had recognized 
self-regulation as a mediator in the relationship between anxiety and achievement. Ning and Downing (2012) observed that self-regulation played a mediating role between learning experiences and academic performance. Lee et al. (2012) indicated that students needed to develop self-regulation skills of their own to achieve long-term goals; furthermore, students who possessed self-regulation were more likely to be successful over the course of their school lives. According to the aforementioned studies, SRL plays a key role in mediating the relationship between TA and achievement. Therefore, we proposed the following hypothesis:

$\mathrm{H}_{2}$ : Self-regulated learning (SRL) mediates the relationship between TA and achievement in accounting courses.

\subsection{Cognitive Style Differences in the Learning Process}

Cognitive styles have been described as consistent and enduring differences in individual organization and functioning (Ausubel et al., 1978). This construct is often used in the field of educational research (DeTure, 2004; Riding \& Watts, 1997) to determine how cognitive style affects the learning behaviour of individuals. Sternberg (1997) defined cognitive style as the preferred mode of the individual to interpret information, solve, and memorize. Cognitive style can also be described as a stable, persistent personality dimension capable of influencing attitudes, values, and social interactions ((Allinson \& Hayes, 1996; Riding \& Watts, 1997); specifically, the cognitive style of an individual is dictated by his/her personal preference for processing information. According to Allinson and Hayes (1996), cognitive style has two dimensions: analytical and intuitive. The analytical dimension describes linear, sequential processing of information as a means for evaluating information for future planning. Thus, individuals with an analytical cognitive style (ACS) may display competency in judging and evaluating information and in selecting actions to implement (Olson, 1985). Individuals with an intuitive cognitive style (ICS), in contrast, are more likely to discover opportunities by observing cues or signals through unfamiliar and unorganized information that is processed in a synthetic and holistic manner (Olson, 1985). Thus, ICS may be useful in the search stage of creating a new venture (Miner, 1997). Past studies have indicated that the learning process is different for analytical and intuitive students. For example, Graff (2003) indicated that students demonstrating ICS learned better compared with ACS students when faced with piecemeal teaching content. Thus, this study proposed the following hypothesis:

H3: Analytical cognitive style (ACS) and intuitive cognitive style (ICS) have different SRL-mediated effects on achievement among students in accounting courses.

Figure 1 shows the postulated research model based on the discussion above. 


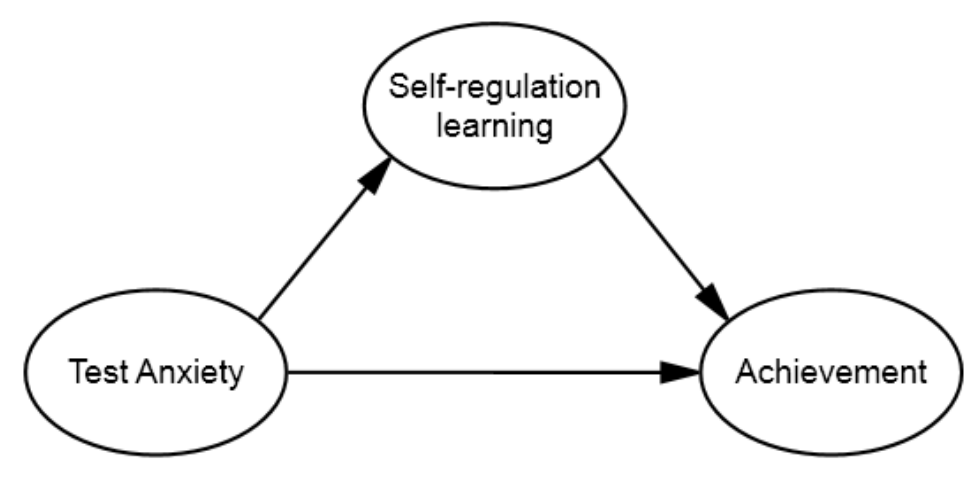

Figure 1. Research model

\section{Method}

\subsection{Participants}

Data were collected in two phases, separated by a period of about 2 months, from the finance programs of six universities across Taiwan. In each school, two classes of first-year students were selected. In the first phase, a self-administrated questionnaire was used that included questions about TA, self-efficacy, and cognitive style. After two months, all 565 freshmen enrolled in the accounting program were asked fill in a self-report questionnaire of SRL behaviour and to take an accounting test. A total of 550 participants completed both phases of data collection, and a total of 498 useable responses were received, yielding a response rate of $91 \%$. Most respondents were $19-21$ years of age $(96 \%)($ Mean $=19.32 ; \mathrm{SD}=0.35)$ and female $(333,66.86 \%)$. To address the issue of nonresponse bias, the mean difference was compared between the top one-third (i.e., the top 166) and bottom one-third (the bottom 166) of all respondents; no statistically significant differences were evident with regard to the variables addressed in this research (Armstrong \& Overton, 1977). The respective p-values were 0.31 for TA and 0.72 for SRL. The p-value for cognitive style was 0.92 .

\subsection{Measures}

The measures used in the current research were based on existing measures that have demonstrated reliability and validity in the existing literature. The items included in the survey were compiled in English and then translated into Mandarin by translation / back-translation (Brislin, 1976). The items were rated using a seven-point scale, with 1 corresponding to "total disagreement" and 7 corresponding to "total agreement." Some items were reworded slightly for adaptation to the present setting.

\subsubsection{Test Anxiety (TA)}

TA was measured using an approach adapted from Pintrich and De Groot (1990), with four items. Sample items included the following: "I am so nervous during a test that I cannot remember facts that I have learned" and "When I take a test, I think about how poorly I am doing." The Cronbach's alpha was 0.81 . 


\subsubsection{Self-Regulated Learning (SRL)}

The SRL behaviour questionnaire, adopted from Kurman (2004, 2006), included six items, including the following sample items: "I did all of my homework" and "I was very attentive in class." Cronbach's alpha was 0.85 .

\subsubsection{Cognitive Style}

Cognitive style was measured using a seven-point scale for self-development taken from Allinson and Hayes (1996). Two subscales were included for ICS and ACS. ICS was measured by five items, such as "I fully believe that my hunch is correct. The Cronbach's alpha was 0.91. ACS was measured by five items and included sample items such as "I like complex problems more than simple questions. The Cronbach's alpha was 0.90 .

\subsubsection{Achievement (ACH)}

After two months of the first phase, all students participated in an accounting test. The test, achievement test, the Accounting Achievement Test (ACH; Bureau of Employment and Vocational Training, 2012) is a standardized test based on a study by Cheng and Chiou (2010). To create the test, questions were selected from field test banks via random sampling. The criteria for grading the papers were based on the standards set by the Bureau of Employment and Vocational Training, Executive Yuan, with scores ranging from 0 to 100. The test took approximately $110 \mathrm{~min}$ to complete. The present study followed Lee et al. (2012) in converting the grade of each student into an $\mathrm{ACH}$ score. The $\mathrm{ACH}$ scores were classified into nine categories: $<60$ points, $60-64$ points, $65-69$ points, $70-74$ points, $75-79$ points, $80-84$ points, $85-89$ points, $90-94$ points, and $>94$ points.

\subsubsection{Assessment of Measures}

This study used maximum likelihood estimation procedures to prevent violation of the normality assumption (Curran et al., 1996). Following the guidelines for severe non-normality (i.e., an absolute skewness value $>3$ and an absolute kurtosis value $>10$ ) proposed by Kline (2005), all items fell well within the guidelines and could be regarded as fairly normal for purposes of further analysis. In what follows, we report on the reliability of the scales, including their convergent and discriminant validity.

\subsection{Convergent Validity}

According to Hair et al. (2006), items belonging to a specific construct should converge or share a high proportion of the variance (i.e., convergent validity). Most researchers (e.g., Fornell \& Larcker, 1981) have promoted three major indictors of convergent validity: factor loading, average variance extracted (AVE), and construct reliability (CR). The factor loading of all items in the present research ranged from 0.71 to 0.89 . Tables 1 show that all the mean and standard deviation of five measures, reveals the measure ACS has largest mean and the measure SRL has smallest mean, the measure ACH has largest standard deviation and the measure of TA and SRL has smallest standard deviation, and also shows the pair correlation matrices are positive relationship for the construct in the model and reveals the square root of AVE in the diagonal elements, and the all CR values greater than 0.7 and all AVE values 
greater than 0.5 ; thus, the constructs in the research model generally exhibited acceptable convergence (Fornell \& Larcker, 1981).

\subsection{Discriminant Validity}

Discriminant validity can be used to measure the extent to which constructs differ. The square root of the AVE for a specific construct must be greater than the correlation estimates between that construct and all other constructs to achieve adequate discriminant validity (Fornell \& Larcker, 1981). Table 1 shows the correlation matrices for the constructs in the model. The diagonal elements (the square roots of the AVE) were greater than the off-diagonal elements (the correlation coefficients) in corresponding rows and columns. This implies that each construct shared greater variance with its subordinate items than with items subordinate to other constructs. Hair et al. (2006) suggested that discriminant validity exists when an item correlates more highly with items within the same construct than it does with items within other constructs. Thus, a satisfactory level of discriminant validity was demonstrated at the item level for the model.

Table 1. Descriptive data for measures and correlation matrix information for constructs

\begin{tabular}{lllrccllll}
\hline & M & SD & CR & AVE & 1 & 2 & 3 & 4 & 5 \\
\hline 1-ACH & 4.18 & 2.25 & -- & -- & -- & & & & \\
2-TA & 4.23 & 0.96 & .87 & .62 & -.20 & $(.79)$ & & & \\
3-SRL & 3.98 & 0.96 & .93 & .67 & .15 & .37 & $(.82)$ & & \\
4-ICS & 4.59 & 1.07 & .90 & .66 & .09 & .12 & .51 & $(.82)$ & \\
5-ACS & 4.75 & 0.97 & .91 & .67 & .12 & .10 & .16 & .32 & $(.81)$ \\
\hline
\end{tabular}

Notes:

All correlation coefficients are significant at the level of .01 in two tailed-tests. Diagonal (in brackets): square root of average variance extracted from observed variables (items); Off-diagonal: correlations between constructs.

\subsection{Test of the Measurement Model}

Confirmatory factor analysis (CFA) using AMOS 16.0 was conducted to validate the measurement model. The fit indices for the model were as follows: $\chi^{2}=1016.89, d f=340$, Norm $\chi^{2}=2.99(<3), G F I=0.89(>0.80), A G F I=0.84(>0.80), C F I=0.94(>0.90)$, and RMSEA $=0.01(<0.08)$. Based on these values, most researchers would consider this model to be reasonable, providing a good representation of the data (Baumgartner \& Homburg, 1996, Hair et al., 2006; Kline, 2005). All of the items in the model had significant parameter estimates with standardized estimates $>0.50$. These results also suggest that these data reflect satisfactory convergent validity for each subscale, as each subscale was able to explain the items it measured better than it was able to explain the items on the other subscales (Fornell \& Larcker, 1981). 


\section{Results}

Three analyzes were performed. First, the correlation between TA and ACH was calculated. Second, the question of whether SRL mediated the relationship between TA and ACH was addressed. Finally, the effect of cognitive style was investigated with respect to the learning processes. The correlation between TA and the ACH score was found to be significant $(\mathrm{r}=$ $-0.20, \mathrm{p}<0.01$, see Table 1). Thus, hypothesis H1 was supported.

\subsection{Mediating Role of Self-Regulated Learning (SRL)}

The mediated regression procedures developed by Baron and Kenny (1986) were used to test the models. These procedures involved the specification of several regression equations to identify mediating relationships among variables. Figure 2 shows the results for mediated regression analysis of SRL. SRL partially mediated the effect of TA on ACH (Sobel Z $=4.31$, $\mathrm{p}<0.001)$. Thus, SRL was a significant mediator of the effect of TA on ACH. The direct, indirect, and overall effect of $\mathrm{TA}$ on $\mathrm{ACH}$ were $-0.20,0.08$, and -0.12 , respectively. Therefore, the indirect effect (0.08) of TA on ACH was greater than its direct effect $(-0.20)$. This implies that SRL was the key mediator influencing ACH. Thus, hypothesis H2 was supported.

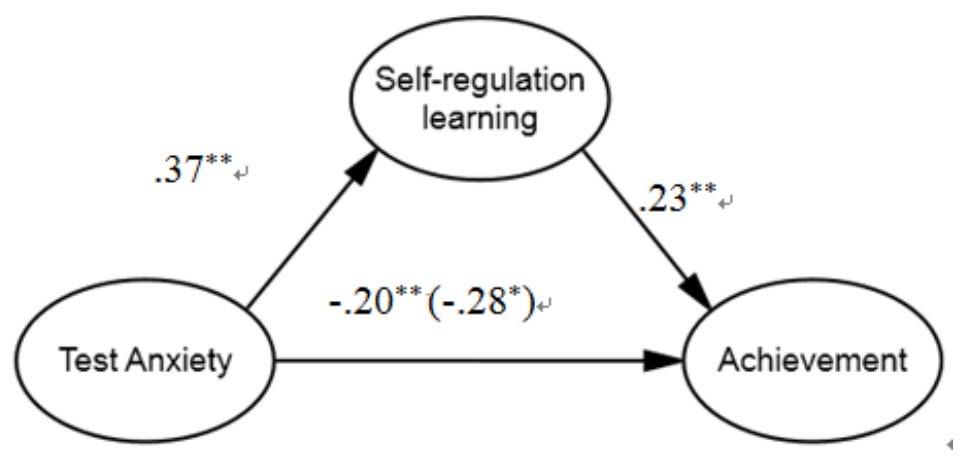

Figure 2. SRL Partial mediated the effect of TA on ACH

\subsection{Impact of Cognitive Style}

The present research calculated the score for learners' cognitive styles using a two-stage cluster procedure adopted from Punj and Stewart (1983). Referring to the rules for coherency, the increment for the coefficient of coherency was $57.22 \%$ when the sample data were split into two groups, accompanied by a sharp increase in the variance increment. Thus, the fitting group for the sample was no more than three clusters. Then change another method, tree diagram, decision fitting clusters. Consequently, that is more fit that the sample date was split two groups. The k-means method was used in the second stage. The analytical subsample included 188 participants (male: 106; female: 82), and the intuitive subsample included 310 participants (male: 59; female: 251). Ten pairs of coordinates (ACS, ICS) were used for the individual measurement variables: X1 (5.88, 4.29), X2 (5.73, 3.93), X3 (5.74, 3.94), X4 (5.68, 


\section{Macrothink}

3.83), X5 (5.84, 4.03), X6 (5.86, 4.21), X7 (5.94, 4.42), X8 (5.85, 4.31), X9 (5.55, 4.31), and $\mathrm{X} 10(5.52,4.36)$. The t-values of all 10 coordinates for the two groups were statistically significant.

The mediating role of SRL was evaluated for the ACS and ICS groups. Figures 3 and 4 show the results from mediated regression analysis of SRL for ACS and ICS students, respectively. For the ACS students, SRL partially mediated the effect of TA on ACH (Sobel Z = 3.36, p < 0.01 ). The direct, indirect, and overall effects of TA on $\mathrm{ACH}$ were $-0.26,0.14$, and -0.12 , respectively. Therefore, the indirect effect (0.14) of TA on ACH was greater than its direct effect (-0.26). This implies that SRL was also the key mediator influencing ACH for the ACS samples. For the ICS students, SRL partially mediated the effect of TA on ACH (Sobel Z = 3.03, $\mathrm{p}<0.001)$. Thus, SRL was a significant mediator of the effect of TA on ACH for the ACS sample. The direct, indirect, and overall effects of TA on ACH were $-0.17,0.06$, and -0.11 , respectively. The indirect effect (0.06) of TA on ACH was greater than its direct effect $(-0.17)$. This implies that SRL was also a key mediator influencing ACH for the ICS sample. Thus, H3 was supported.

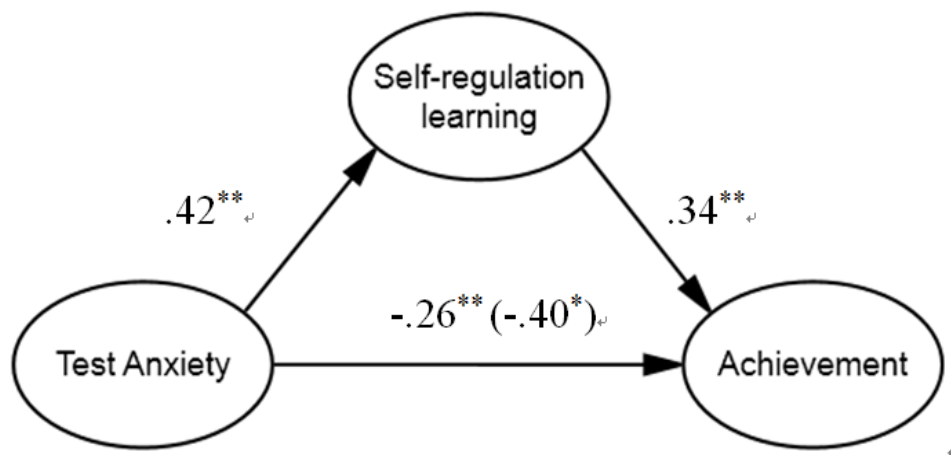

Figure 3. SRL partially mediated the effect of TA on ACH (ACS)

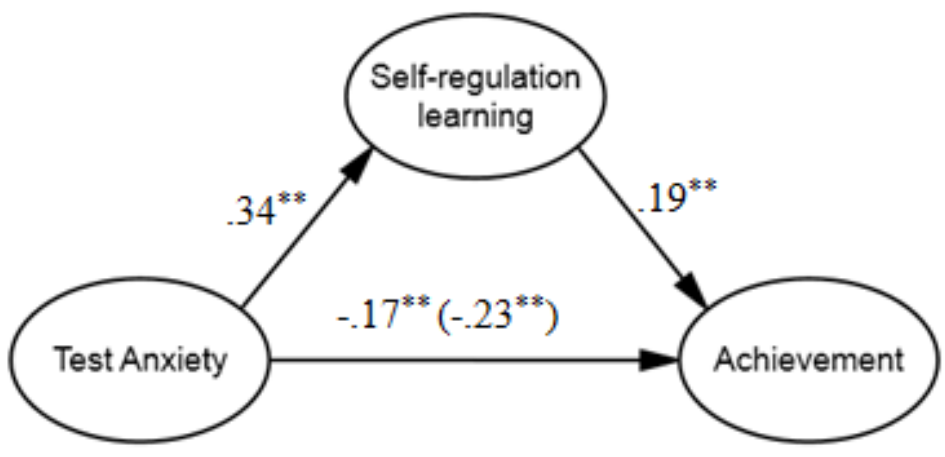

Figure 4. SRL partially mediated the effect of TA on ACH (ICS) 


\section{Discussion}

A possible interpretation of these findings contributes to the theoretical understanding and educational contributions of TA, SRL and cognitive style in students' achievement in accounting courses. This study also compared factors related to gender analysis and ACS versus ICS that may affect the relationship between TA and ACH. The results of this study have implications in three important areas: the relationship between TA and $\mathrm{ACH}$; the mediating role of SRL; and differential relationships among TA, SRL according to the two cognitive styles (ACS and ICS).

Our study revealed that students with TA have low ACH and vice versa. The results echoed previous findings from similar research (e.g., Nicholson, 2009; Rana \& Mahmood, 2010). Furthermore, the gender differences in the relationship TA and ACH indicated a lower path coefficient for female students $(\beta=-0.22)$ in the relationship between TA and ACH compared with that for males $(\beta=-0.25)$. These results differ from other gender-based TA studies, in which higher levels of TA were observed in females than in males (e.g., Chapell et al., 2005; Rana \& Mahmood, 2010). This discrepancy was attributed to the large percentage of females enrolled in college/university business departments in Taiwan compared with the number of males.

The second topic under consideration was our finding indicating that SRL mediated the relationship between TA and $\mathrm{ACH}$. These results were in good agreement with the findings of Stanley and Marsden (2012) and suggest the use of problem-based learning (PBL) in accounting education. Additionally, the results in the present study confirmed that accounting educators could indirectly improve students' ACH through SRL strategies. For example, Buckhaults and Fisher (2011) demonstrated that accounting educators could lower students' anxiety and increase their motivation to learn using appropriate materials and new teaching methods. These results echoed the findings of Hofer et al. (1998), who described interventions to facilitate students" "learning to learn," a particularly important factor in undergraduate-level coursework. Although SRL interventions exist for all male and female groups across a variety of domains, they are generally more concentrated at the college level, particularly in the form of "study skills" courses (e.g., accounting courses) (Weinstein et al., 2000). Our results also revealed a lack of review and preparation for accounting class (< 35\%), consistent with other studies (e.g., Chen et al., 2013; Peng, 2004). Thus, the appropriate SRL for individual students is very important. Some researchers have determined that self-regulatory processes are teachable (Mills et al., 2007). Pajares (2002) also recommended that teachers evaluate the confidence level of their students in formulating and following self-regulatory strategies. Our results showed that male students were more adept at using $\operatorname{SRL}(\beta=0.34)$ in accounting classes than were female students $(\beta=0.30)$; additionally, the indirect effect $(0.19)$ for male students was greater than that $(0.11)$ for female students. Note that this result was not consistent with the results of Pokay and Blumenfeld (1990), whose results showed that girls used more SRL strategies than boys did in high school courses. The discrepancies in the research findings discussed above require additional study. 
Additionally, our study determined that SRL fully mediated the effect of TA on ACH for male students, but only partially mediated this effect for female students. In other words, when male and female students experience TA, SRL strategies are likely to result in different outcomes. Our results suggest that male students tended to minimize or ignore TA, whereas female students tended to be more affected by TA.

The three issue was the comparison of the learning process reflected in two cognitive styles: the analytic cognitive style (ACS) and intuitive cognitive style (ICS). Of the 498 participants, $64 \%$ of male and $25 \%$ of female students were classified as ACS; $75 \%$ of females and $36 \%$ of males were classified as ICS. This result is consistent with the findings of Epstein et al. (1996), it implies that male students prefer analytical processing of problems to intuitive problem-solving techniques, whereas female students preferred intuitive processing. Our results suggest that adopting both approaches would improve the effectiveness of accounting education, particularly in its being able to reach students with differing cognitive styles (Duff, 2004).

The classification of cognitive style into ACS or ICS in the present research was based on the findings of Allinson and Hayes (1996). The analytic cognitive style is characterized by judgments based on rationality, whereas the intuitive cognitive style is characterized by immediate reactions based on feelings (Allinson \& Hayes, 1988, 1990). In the present study, our results indicated that SRL had a slightly larger indirect effect (0.14) on ACS students compared with its indirect effect (0.06) on ICS students. Thus, students in the ACS group exhibited better SRL learning strategies than did those the ICS group. Additionally, the results revealed that GSE and ASE predicted 21 and $23 \%$ of the variability in ACH for the ACS students and 16 and $21 \%$ of the variability in ACH for the ICS students, respectively. The results suggest that the accounting faculty who encourage ACS in their teaching better prepare students in "learning how to learn," which may lead to improved ACH for their students.

\subsection{Limitations and Future Research}

In interpreting the results of the study, certain limitations must be acknowledged. First, because the current research was cross-sectional in nature, it provided explanations for correlations among variables; however, specific causal relationships could not be determined using this approach. Future research and longitudinal data are needed to provide additional insight into issues of causality. Second, SRL behaviour was assessed by self-reports only, although the measures were validated against external criteria. Nevertheless, in future research, an external evaluation of learning behaviours (e.g., by teachers) could strengthen the research findings. Third, the correlational nature of the study did not allow causal relationships to be inferred. Replication of this research with experimental studies would help to clarify the causal nature of the relationships. Fourth, our research approach raised issues related to common method variance (Cote \& Buckley, 1988); however, our data-collection method should alleviate concerns associated with method variance. Additionally, the length and wording of the questionnaire may have caused participants to spend undue time completing the measure (Podsakoff et al., 2003). Finally, because the current study focused 
only on Taiwanese university students, a cross-cultural research design that allows for direct comparison between cultures would provide more meaningful conclusions.

\subsection{Conclusions}

Despite these limitations, the present study is meaningful. Our results indicated that SRL behaviours are an important strategy for learning in accounting courses. "Learning how to learn" could indirectly enhance student's ACH. Moreover, male and female students revealed different SRL strategies. Finally, the study determined that different cognitive styles require different SRL strategies. Our research results suggest that accounting faculty should adopt a variety of teaching methods to address differences in learning strategies across genders and cognitive styles.

\section{Acknowledgement}

The author would like to dedicate his greatest gratitude to the Ministry of Science and Technology, Taiwan for the financial support (101-2511-S-165 -003 -MY2).

\section{Reference}

Agina, A. M. (2012). The effect of nonhuman's external regulation on young children's self-regulation to regulate their own process of learning. Computers in Human Behavior, 28, 1140-1152. http://dx.doi.org/10.1016/j.chb.2012.01.022

Akinleke, O. W. (2012). An investigation of the relationship between test anxiety, self esteem and academic performance among polytechnic students in Nigeria. International Journal of Computer Application, 51(1), 47-50. http://dx.doi.org/10.5120/8010-1376

Allinson, C. W., \& Hayes, J. (1988). The learning styles questionnaire: An alternative to Kolb's inventory? Journal of Management Studies, 25, 269-281. http://dx.doi.org/10.1111/j.1467-6486.1988.tb00036.x

Allinson, C. W., \& Hayes, J. (1990). Validity of the learning styles questionnaire. Psychological Reports, 67, 859-866. http://dx.doi.org/10.2466/PR0.67.7.859-866

Allinson, C. W., \& Hayes, C. (1996). The cognitive style index: A measure of intuition-analysis for organizational research. Journal of Management Studies, 33, 119-135. http://dx.doi.org/10.1111/j.1467-6486.1996.tb00801.x

Ameen, E. C., Guffey, D. M., \& Jackson, C. (2002). Evidence of teaching anxiety among accounting educators. Journal of Education for Business, 78, 16-22. http://dx.doi.org/10.1080/08832320209599692

Andrade, M. \& Williams, K. (2009). Foreign languages learning anxiety in Japanese EFL university classes: Physical, emotional, expressive, and verbal reactions. Sophia Junior College Faculty Journal, 29, 1-24.

Andrew, H., \& Karen, B. (2011). Relations among mindfulness, achievement-related self-regulation, and achievement emotions. Journal of Happiness Studies, 12(6), 1007-1022. http://dx.doi.org/10.1007/s10902-010-9241-7 
Armstrong, J. S., \& Overton, T. S. (1977). Estimating nonresponse bias in mail surveys. Journal of Marketing Research, 14, 396-402. http://dx.doi.org/10.2307/3150783

Ausubel, D. P., Novak, J. D., \& Hanesian, H. (1978). Journal of educational psychology: A cognitive view (2nd ed.). New York: Holt, Rinehart, \& Winston.

Baloğlu, M., \& Çevik, V. (2009). A multivariate comparison of computer anxiety levels between candidate and tenured school principals. Computer in Human Behavior, 25, 1102-1107. http://dx.doi.org/10.1016/j.chb.2009.05.007

Baron, R. M., \& Kenny, D. A. (1986). The moderator-mediator variable distinction in social psychological research: Conceptual, strategic, and statistical considerations. Journal of $\begin{array}{llll}\text { Personality } \quad \text { and Social } & \text { Psychology, } & \text { 51(6), } & \text { 1173-1182. }\end{array}$ http://dx.doi.org/10.1037/0022-3514.51.6.1173

Baumgartner, H., \& Homburg, C. (1996). Applications of structural equation modeling in marketing and consumer research: A review. International Journal of Research Marketing, 13(2), 139-161. http://dx.doi.org/10.1016/0167-8116(95)00038-0

Bandura, A. (1997). Self-efficacy: The excise of control. New York: W. H. Freeman.

Bembenutty, H. (2007). Self-regulation of learning and academic delay of gratification: gender and ethnic differences among students. Journal of Advanced Academics, 18(4), 586-616.

Booth, P., Luckett, P., \& Mladenovic, R. (1999). The quality of learning in accounting education: The impact of approaches to learning on academic performance. Accounting Education, 8, 277-300. http://dx.doi.org/10.1080/096392899330801

Borja, P. M. (2003). So you've been asked to teach principles of accounting. Business Education Forum, 58, 30-32.

Brislin, R. W. (1976). Comparative research methodology: Cross cultural studies. International Journal of Psychology, 11(3), 215-229. http://dx.doi.org/10.1080/00207597608247359

Buckhaults, J., \& Fisher, D. (2011). Trends in accounting education: Decreasing accounting anxiety and promoting new methods. Journal of Education for Business, 86, 31-50. http://dx.doi.org/10.1080/08832321003720692

Bureau of Employment and Vocational Training. (2012). The Accounting Practice Achievement Test. Taipei, Taiwan: Executive Yuan, Republic of China.

Byrne, M., Flood, B., \& Willis, P. (1999). Approaches to learning: Irish students of accounting. The Irish Accounting Review, 6, 1-29.

Byrne, M., Flood, B. \& Willis, P. (2002). The relationship between learning approaches and learning outcomes: A study of Irish accounting students. Accounting Education, 11, 27-42. http://dx.doi.org/10.1080/09639280210153254 
Chapell, M. S., Blanding, Z. B., Silverstein, M. E., Newman, B., Gubi, A., \& Mccann, N. (2005). Test-anxiety and academic achievement in undergraduate and graduate student. $\begin{array}{lllll}\text { Journal of } & \text { Educational } & \text { Psychology, } & 97(2), & \text { 268-78. }\end{array}$ http://dx.doi.org/10.1037/0022-0663.97.2.268

Chen, B. H., Hsu, M. S., \& Chen., M. H. (2013). The relationship between learning attitude and anxiety in accounting classes: The case of hospitality management university students in Taiwan. Quality \& Quantity, 47, 2815-27. http://dx.doi.org/10.1007/s11135-012-9691-6

Cheng, P.Y., \& Chiou, W. B. (2010). Achievement, attributions, self-efficacy, and goal setting by accounting undergraduates. Psychological Reports, 106(1), 54-64. http://dx.doi.org/10.2466/PR0.106.1.54-64

Cho, M. H., \& Kim, B. J. (2013). Students' self-regulation for interaction with others in online learning environments. Internet and Higher Education, 17, 69-75. http://dx.doi.org/10.1016/j.iheduc.2012.11.001

Clark, C. E., \& Schwartz, B. N. (1989). Accounting anxiety: An experiment to determine the effects of an intervention on anxiety levels and achievement of introductory accounting $\begin{array}{lllll}\text { students. Journal of Accounting } & \text { Education, } & 7, & 149-169 .\end{array}$ http://dx.doi.org/10.1016/0748-5751(89)90002-X

Cohen, J., \& Hanno, D. (1993). An analysis of underlying constructs affecting the choice of accounting as a major. Issues in Accounting Education, 8(2), 219-238.

Cory, S. (1992). Quality and quantity of accounting students and the stereotypical accountant: is there a relationship? Journal of Accounting Education, 10, 1-24. http://dx.doi.org/10.1016/0748-5751(92)90015-W

Cote, J. A., \& Buckley, M. R. (1988). Measurement error and theory testing in consumer research: An illustration of the importance of construct validation. Journal of Consumer Research, 14, 579-582. http://dx.doi.org/10.1086/209137

Curran, P. J., West, S. G. \& Finch, G. F. (1996). The robustness of test statistics to nonnormality and specification error in confirmatory factor analysis. Psychological Methods, 1, 16-29. http://dx.doi.org/ 10.1037//1082-989X.1.1.16

Davidson, R. A. (2002). Relationship of study approach and exam performance. Journal of Accounting Education, 20, 29-44. http://dx.doi.org/10.1016/S0748-5751(01)00025-2

DeTure, M. (2004). Cognitive style and self-efficacy: Predicting student success in online distance education. The American Journal of Distance Education, 18(1), 21-38. http://dx.doi.org/10.1207/s15389286ajde1801_3

Dignath, C., \& Buttner, G. (2008). Components of fostering self-regulated learning among students: A meta-analysis on intervention studies at primary and secondary school level. Metacognition \& Learning, 3, 231-264. http://dx.doi.org/10.1007/s11409-008-9029-x

Dignath, C., Buttner, G., \& Langfeldt, H. P. (2008). How can primary school students learn 
self-regulated learning strategies most effectively? A meta-analysis on self-regulation training $\begin{array}{lllll}\text { programs. } & \text { Educational } & \text { Research } & \text { 101-129. }\end{array}$ http://dx.doi.org/10.1016/j.edurev.2008.02.003

Duff, A. (20 http://dx.doi.org/10.1007/s11409-008-9029-x 04). The role of cognitive learning styles in accounting education: developing learning competencies. Journal of Accounting Education, 22, 29-52. http://dx.doi.org/10.1016/j.jaccedu.2003.09.004

Dyck, J. L., \& Smither, J. A. A., (1996). Older adults' acquisition of world processing: The contribution of cognitive abilities and computer anxiety. Computers in Human Behavior, 12, 107-119. http://dx.doi.org/10.1016/0747-5632(95)00022-4

Epstein, S., Pacini, R. Denes-Raj, V. \& Heier, H. (1996). Individual differences in intuitive-experiential and analytical-rational thinking styles. Journal of Personality and Social Psychology, 71(2), 390-405. http://dx.doi.org/10.1037/0022-3514.71.2.390

Fisher, J., \& Murphy, V. (1995). A pariah profession? Some student perceptions of accounting and accountancy. Studies in Higher Education, 20(1), 45-58. http://dx.doi.org/10.1080/03075079512331381790

Fornell, C., \& Larcker, D. F. (1981). Evaluating structural equation models with unobservable and measurement errors. Journal of Marketing Research, 18, 39-50. http://dx.doi.org/10.2307/3150979

Friedlan, J. (1995). The effects of different teaching approaches on students' perceptions of skills needed for success in accounting courses and by practicing accountants. Issues in Accounting Education, 10(1), 47-63.

Gow, L., Kember, D. \& Cooper, B. (1994). The teaching context and approaches to study of accounting students. Issues in Accounting Education, 9, 118-130.

Graff, M. (2003). Learning form web-based instructional systems and cognitive style. British Journal of Educational Psychology, 34(4), 407-418.

Grau, V., \& Whitebread, D. (2012). Self and social regulation of learning during collaborative activities in the classroom: The interplay of individual and group cognition. Learning and Instruction, 22, 401-412. http://dx.doi.org/10.1016/j.learninstruc.2012.03.003

Hair, Jr. F., Black, W. C. Babin, B. J., Anderson, R. E. \& Tatham, R. L. (2006). Multivariate Data Analysis (6th ed.). New York: Macmillan.

Hanfstingl, B., Andreitz, I. Muller, F. H. \& Thomas, A. (2010). Are self-regulation and self-control mediators between psychological basic needs and intrinsic teacher motivation? Journal for Educational Research Online, 2(2), 55-71.

Hofer, B., Yu, S., \& Pintrich, P. R. (1998). Teaching college students to be self-regulated learners. In Self-regulated learning: From teaching to self-reflective practice, edited by D.H. Schunk and B.J. Zimmerman (eds.), 57-85. New York: Guilford Press.

Hong, Z. R. (2010). Effects of a collaborative science intervention on high achieving 
students' learning anxiety and attitudes toward science. International Journal of Science Education, 32, 1971-88. http://dx.doi.org/10.1080/09500690903229304

Khalid, R., \& Hasan, S. S. (2009). Test anxiety in high and low achievers. Pakistan Journal of Psychological Research, 24(3-4), 97-114.

Kline, R. B. (2005). Principles and Practice of Structural Equation Modeling (2 ${ }^{\text {nd }}$ ed.). New York: Guilford.

Koh, M. Y., \& Koh, H. C. (1999). The determinants of performance in an accountancy degree program. Journal of Accounting Education, $\quad 8, \quad 13-29$. http://dx.doi.org/10.1080/096392899331017

Kurman, J. (2004). Gender, self-enhancement, and self-regulation of learning behaviors in

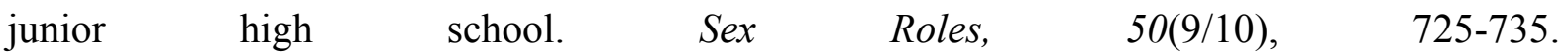
http://dx.doi.org/10.1023/B:SERS.0000027573.36376.69

Kurman, J. (2006). Self-enhancement, self-regulation, and self-improvement following failure. British Journal of Social Psychology, 45(2), 339-56. http://dx.doi.org/10.1348/014466605X42912

Kurt, A. A., \& Gurcan, A. (2010). The comparison of being strategies, computer anxiety and success states of students taking web-based and face-to-face instruction in higher education. Procedia - Social and Behavioral Sciences, 9, 1153-1157. http://dx.doi.org/10.1016/j.sbspro.2010.12.299

Lee, J., Yu, H., \& Choi, S. (2012). The influences of parental acceptance and parental control on school adjustment and academic achievement for southern Korean children: The mediation role of self-regulation. Asia Pacific Education Review, 13(2), 227-237. http://dx.doi.org/10.1007/s12564-011-9186-5

Lewis, A. (1970). The ambiguous word anxiety. International Journal of Psychiatry, 9, 62-79.

Lucas, U. (2000). Worlds apart: students' approaches to learning introductory accounting. Critical Perspectives on Accounting, 11, 479-504. http://dx.doi.org/10.1006/cpac.1999.0390

Lucas, U. (2001). Deep and surface approaches to learning within introductory accounting: A phenomenographic study. Journal of Accounting Education, 10, 161-84. http://dx.doi.org/10.1080/09639280110073443

Lucas, U. (2002). Uncertainties and contradictions: Lecturers' conceptions of teaching introductory accounting. British Accounting Review, 34, 183-204. http://dx.doi.org/10.1006/bare.2002.0197

Lucas, U., \& Meyer, J. H. G. (2005). Towards a mapping of the student world: the identification of variation in students' conceptions of, and motivations to learn, introductory accounting. The British Accounting Review, 37, 177-204. http://dx.doi.org/10.1016/j.bar.2004.10.002 
Matthews, G., Hillyard, E. J. \& Campbell, S. E. (1999). Metacognition and maladaptive coping as components of test anxiety. Clinical Psychology and Psychotherapy, 6, 111-25. http://dx.doi.org/10.1002/(SICI)1099-0879(199905)6:2<111::AID-CPP192>3.0.CO;2-4

Mills, N., Pajares, F. \& Herron, C. (2007). Self-efficacy of college intermediate french students: relation to achievement and motivation. Language Learning, 57(3), 417-42. http://dx.doi.org/10.1111/j.1467-9922.2007.00421.x

Miner, J. B. (1997). A Psychological Typology of Successful Entrepreneurs. London: Quorum Books.

Mladenovic, R. (2000). An investigation into ways of challenging introductory accounting students' negative perceptions of accounting. Journal of Accounting Education, 9, 135-155. http://dx.doi.org/10.1080/09639280010000147

Nicholson, A. M. (2009). Effects of test Anxiety on student achievement for college bound students. Dissertation Abstract International, 3366126.

Ning, H. M., \& Downing, K. (2012). Influence of student learning experience on academic performance: The mediator and moderator effects of self-regulation and motivation. British Educational Research Journal, 38(2), 219-237. http://dx.doi.org/10.1080/01411926.2010.538468

Olson, P. D. (1985). Entrepreneurship: Process and abilities. American Journal of Small Business, 10(1), 25-31.

Onwuegbuzie, A. J. (2004). Academic procrastination and statistics anxiety. Assessment \& Evaluation in Higher Education, 29, 3-19. http://dx.doi.org/10.1080/0260293042000160384

Onyeizugbo, E. U. (2010). Self-efficacy and test anxiety as correlates of academic performance. Educational Research, 1(10), 477-480.

Pajares, F. (2002). Gender and perceived se in self-regulated learning. Theory into Practice, 41(2), 116-125. http://dx.doi.org/10.1207/s15430421tip4102_8

Peng, S. S. (2004). Taiwan higher education data system and Its applications (II). National Science Council of R.O.C. NSC 93-2413-H-007-002.

Pintrich, P. R., \& De Groot. E. V. (1990). Motivational and self-regulated learning components of classroom academic performance. Journal of Educational Psychology, 82, 33-40. http://dx.doi.org/10.1037/0022-0663.82.1.33

Podsakoff, P.M., Mackenzie, S.B. Lee, J. Y. \& Podsakoff, N. P. (2003). Common method biases in behavioral research: A critical review of the literature and recommended. Journal of Applied Psychology, 88, 879-903. http://dx.doi.org/10.1037/0021-9010.88.5.879

Pokay, P., \& Blumenfeld, P. C. (1990). Predicting achievement early and late in the semester: The role of motivation and use of learning strategies. Journal of Educational Psychology, 82, 41-50. http://dx.doi.org/10.1037/0022-0663.82.1.41 
Printrich, P. R. (2000). Multiple goals, multiple pathways: The role of goal orientation in learning and achievement. Journal of Educational Psychology, 92, 544-555. http://dx.doi.org/10.1037/0022-0663.92.3.544

Printrich, P. R., \& Zusho, A. (2007). A student motivation and self-regulation learning in the college classroom. In The Scholarship of teaching and Learning in Higher Education: An Evidence-Based Perspective edited by R.O. Perry, and J. C. Smart (eds.), 731-810. Dordrecht, the Netherlands: Springer. http://dx.doi.org/10.1007/1-4020-5742-3_16

Punj, G., \& Stewart. D. W. (1983). Cluster analysis in marketing research: Review and suggestions for application. Journal of Marketing Research, 20(2), 134-48. http://dx.doi.org/10.2307/3151680

Ramsay, A., Hanlon, D. \& Smith, D. (2000). The association between cognitive style and accounting students' preference for cooperative learning: An empirical investigation. Journal of Accounting Education, 18, 215-28. http://dx.doi.org/10.1016/S0748-5751(00)00018-X

Rana, R.A., \& Mahmood, N. (2010). The relationship between test anxiety and academic achievement. Bulletin of Education and Research, 32(2), 63-74.

Riding, R. J., \& Watts, M. (1997). The effect of cognitive style on the preferred format of $\begin{array}{lllll}\text { instructional material. Educational } & \text { Psychology, } & \text { 17, }\end{array}$ http://dx.doi.org/10.1080/0144341970170113

Saudagaran, S. M. (1996). The first course in accounting: An innovative approach. Issues in Accounting Education, 11(1), 83-94.

Spielberger, C. D. (1983). Manual for the State-trait Anxiety Inventory. Consulting Psychologists Press, Palo Alto.

Spielberger, C. D., Gorsuch, R. L., Lushene, R., Vagg, P. R. \& Jacobs, G. A., (1983). State-trait Anxiety Inventory for Adults. Consulting Psychological Press Inc., Canada.

Stanley, T., \& Marsden, S. (2012). Problem-based learning: Does accounting education need It? Journal Accounting Education, 30, 267-289. http://dx.doi.org/10.1016/j.jaccedu.2012.08.005

Sternberg, R. J. (1997). Thinking Styles. New York: Cambridge University Press. http://dx.doi.org/10.1017/CBO9780511584152

Warren, C.S., Reeve, J. M. \& Duchac, J. E. (2007). Accounting. In Introduction to Accounting and Business by S. Oblinger, S. E. Joos, \& E. Berger (Eds.), 1-47, Mason, OH: Thomson South-Western.

Weinstein, C. E., Husman, J., \& Dierking, D. R. (2000). Interventions with a focus on learning strategies. In Handbook of Self-Regulation, edited by Boekaerts, M. Printrich, P. R., \& Zeidner, M. (eds.), 727-747. San Diego, Calif.: Academic Press. http://dx.doi.org/10.1016/B978-012109890-2/50051-2

Weinstein, C. E., Tomberlin, T. L., Julie, A. L., \& Kim, J. (2004). Helping students to become 


\section{Macrothink}

International Research in Education

ISSN 2327-5499

2016, Vol. 4, No. 2

strategic learners: The roles of assessment, teachers, instruction, and students. In Thinking about Thinking: What Educators Need to Know, edited by J. E, A Chang, and O. Tan (eds.), 282-310. Singapore: McGraw-Hill.

Wilkinson, J. D., \& Campbell, E. A. (1997). Psychology in Counselling and Therapeutic Practice. Wiley, Chichester.

White, K. S., \& Farrell, A. D. (2001). Structure of anxiety symptoms in urban children: Competing factor modes of the revised children's manifest anxiety scale. Journal of Clinical Psychology, 69(2), 333-337. http://dx.doi.org/10.1037/0022-006x.69.2.333

Zeidner, M. (1991). Statistics and mathematics anxiety in social science students - some interesting parallels. British Journal of Educational Psychology, 61, 319-328. http://dx.doi.org/10.1111/j.2044-8279.1991.tb00989.x

Zimmerman, B. J. (2000). Attaining self-regulation: A social cognitive perspective. In Handbook of Self-regulation: Theory, Research and Applications, edited by Boekaerts, M., Pintrich. P. R., \& Zeidner, M. (eds.), 13-39. San Diego, Calif.: Academic Press. http://dx.doi.org/10.1016/B978-012109890-2/50031-7

\section{Copyright Disclaimer}

Copyright reserved by the authors.

This article is an open-access article distributed under the terms and conditions of the Creative Commons Attribution license (http://creativecommons.org/licenses/by/3.0/). 